ESJ Social Sciences

\title{
Impact of COVID-19 on Global Container Shipping Industry
}

\author{
Dr. Irakli Danelia
}

Department of International Economics and History of Economic Thoughts, Faculty of Economics and Business, Tbilisi State University (TSU), Georgia

Doi:10.19044/esj.2021.v17n27p5

Submitted: 12 July 2021

Accepted: 12 August 2021

Published: 31 August 2021
Copyright 2021 Author(s)

Under Creative Commons BY-NC-ND

4.0 OPEN ACCESS

Cite As:

Irakli D. (2021). Impact of COVID-19 on Global Container Shipping Industry. European Scientific Journal, ESJ, 17 (27), 5. https://doi.org/10.19044/esj.2021.v17n27p5

\begin{abstract}
This paper demonstrates the Global economic outlook resulted by COVID-19 pandemic and provides an analysis of the direct and indirect impact on Global Container shipping industry. It also discussed sequential interdependence among Pandemic, Global Economic downturn, and Challenges in Global Containerized cargo flows. The paper analysis actual results and the features of the economic crisis caused by COVID-19 pandemic on Global Container shipping industry. While Identifying key determinants of accelerating challenges for Containerized Cargo flows during the global pandemic, the paper concludes short and long terms expectations that might be defined for Future development in the global container Shipping industry.
\end{abstract}

Keywords: COVID-19; Global Economy; Global Container Shipping Industry; Global trade; Container

\section{Introduction}

Since the outbreak of COVID-19 in China, the world economy is passing in a disorder situation. The COVID-19 pandemic has damaged the global economy. Due to the heavy lockdown of almost all the countries, economic activities around the World have dropped in a very significant manner. According to the International Economic organizations majority of the nations faced a negative GDP growth results in Pandemic year of 2020.

The COVID-19 has greatly affected the global economy in terms of global economic growth, global trade, economic development, and resultant economic policy challenges. The Centra banks, International Monetary 
Fund, World Bank and other monetary institutions had to announce concessions and revise their policies during the pandemic (Jackson, Weiss, Schwarzenberg, \& Nelson, 2020).

The Pandemic has not only become a public health crisis but has also affected the World economic condition. Significant economic impact has already occurred across the globe due to loss of life, reduced productivity, business closures, trade disruption, and devastation of the tourism industry. There are still many uncertainties about the COVID-19 pandemic: about the extent of its spread, its severity in different countries, the length of the outbreak, and whether an initial decline could be followed by a recurrence. But some things are already certain: we know that the economic impact of this pandemic is already immense (Ghosh, 2020). The sudden shutdown of many factories and production farms caused a lot of disruption in supply chain management.

Economic shocks test the resilience and adaptability of the shipping industry and container ports. Each crisis triggers different ramifications in the container market. (Notteboom, T., Pallis, T. \& Rodrigue, 2021)

Economic and financial disruptions are recurring events impacting supply chains, with pandemics considered low probability and high impact events (Luke and Rodrigue, 2008), therefore, The paper analyses the impacts of the COVID-19 pandemic on global container shipping industry and supply chains as a whole.

For COVID-19, the situation is very different since it concerns an external shock that rapidly impacted all elements of the supply chain roughly at the same time. (Notteboom, T., Pallis, T. \& Rodrigue, 2021)

Container Shipping is a primary industry for almost all countries globally and serves as an integral part of the Global supply chain for most industries. During the Covid-19 we are dependent on the shipping industry to transport food, medicine, and other necessities across borders. And the shipping industry is dependent on production output to secure cargoes. With lockdowns and closed factories, the coronavirus pandemic has truly put a strain on the Global Container shipping business and negatively impacted on Cargo flow system accordingly.

This paper analyses relative scientific literature, followed by the global pandemic economic outlook, deriving from global Container shipping industry and concentrate on Advanced and Emerging Market Economies. At the end of the paper specific conclusions are made and defined expectations in the development of Global Container Shipping industry for short and long term prospective. 


\section{Literature Review}

Due to the global spread of COVID-19 in March 2020, the World Health Organization (WHO) announced the beginning of a pandemic (Ghebreyesus, 2020). The COVID-19 pandemic has led to a global economic crisis (e.g., Baldwin, Mauro, eds., 2020).

The COVID-19 pandemic caused an economic crisis that almost swept the whole world (e.g., Baldwin, di Mauro, eds., 2020). It should be noted that this crisis is not the result of errors accumulated in the economy. It was caused precisely by a pandemic, when the most effective means of preventing the rapid spread of the coronavirus was to prevent direct communication between people, which caused the lockdown of many sectors of the economy. (Papava, Chkuaseli, 2021). Thus, the economic crisis caused by the COVID-19 pandemic is unique (Ajili, 2020). These challenges include short and longterm fiscal shocks to economic growth. Nonetheless, the direct financial effects of pandemics are generally less compared to the indirect effects on economic growth (Maddhav, 2017).

On March 2, 2020 the Organization for Economic Cooperation and Development (OECD) while lowering the forecast of global economic growth from $2.9 \%$ to $2.4 \%$ based on the presumption that the economic effects of the pandemic may reach its peak during the first four months of 2020. However, the effects of the global economic growth failed to reach its peak, resultantly on March 26, 2020 the OECD had to embark upon on the revision of its economic forecast. This was based upon the continued effects of the pandemic and steps taken by the government for the containment of the spread of the virus. It is important to mention that as per detail of the updated report, global GDP could be reduced by $2.0 \%$ per month or $24 \%$ per year reaching the level of economic contraction that has never been experienced since the Great Economic Depression of 1930s (OECD Interim Economic Assessment, 2020).

In the wake of decline in the economic activity as a "Great Lockdown" the IMF on April 14, 2020 issued an updated forecast. The forecast prognosticated that the global economy would experience its "worst recession since the Great Depression, surpassing that global financial crisis a decade ago" (Fund, 2020). It is also estimated that the world economy could decrease by $3.0 \%$ in 2020 , prior to its increasing by $5.8 \%$ in 2021 ; with the projection of global trade to fall by $11 \%$ in 2020 (IMF, 2020). The IMF also indicated that the world is faced with multi-layered problems including health crisis, economic crisis at domestic level, fall in the external demands of goods, outflows of capitals, and a collapse in the commodity prices.

Covid-19 showed that excessive dependence on East Asia (Mostly China) in manufacturing industry production poses a severe risk for global supply chains. (Fahrad, Nahar, 2020) 
Supply shocks represent an unexpected sudden change in the availability of raw materials, parts, and manufacturing capabilities. It is not just that prices may surge, but the availability of essential components can vanish because of a lack of raw materials, parts, or lack of labor necessary for their procurement. Depending on the existing buffer, such as stockpiles of energy, grain, parts, or raw materials, the supply shock can take some time to be felt across a supply chain. (Notteboom, T., Pallis, T. \& Rodrigue, 2021).

From a supply chain perspective, COVID-19 is unfolding in several sequential phases. The first phase, in early 2020, consisted of a supply shock in China where lockdown measures resulted in a de facto extension of sharply decreased Chinese production during the New Year's period. The lockdown affected most of the workforce and curtailed the industrial base between midJanuary and early March 2020 (Knowler 2020a). Simultaneously, some sectors faced shortages (pharmaceuticals and medical equipment) due to a demand surge and the diversion of inventories (World Health Organization 2020).

The second phase began in mid-March 2020 and consisted of a (global) demand shock with backpropagation along supply chains (Baschuk 2020; World Trade Organization 2020). Various lockdown measures implemented across the world resulted in a decline in global (derived) demand because of lower consumer and industrial confidence and limited retail activity. Service activities associated with the provision of transport services, such as tourism, almost vanished in the first half of 2020. Except for the temporary hoarding shock on inventories, the demand for most consumer products saw a sharp decline. The lockdown of a large consumer base removed people from the workforce and shifted consumption patterns to essential goods (food and personal items). as well as the temporary closure of bars and restaurants, had additional depressing effects on demand (Notteboom, T., Pallis, T. \& Rodrigue, 2021).

Last-mile vulnerabilities in distribution became visible because of the lower availability of the workforce (e.g., absenteeism in trucking). The lower economic activity level and uncertainty about the path to economic recovery also contributed to a steep drop in the price of several commodities. The shift to e-commerce accelerated a process that was already taking place, pressuring online retailers with additional demands. Segments of the luxury sector vanished because of the lockdown, particularly tourism, creating severe disruptions in their supply chains (Notteboom, T., Pallis, T. \& Rodrigue, 2021).

Though researchers and experts are working hard to estimate its impact on the global economy, it is difficult to project its long-term effect. (Bamfo, 2020). Nevertheless, above mentioned observations suggest saying that in general, economic crisis under the COVID-19 pandemic will be impossible to 
overcome until world medicine defeats the pandemic. It means that economy remains hostage to medicine (Papava, 2020).

The global economic recovery might be implemented with an increased risk of protectionism to bust domestic production. Many economies will be in a situation of depressed demand and high unemployment. Moreover, nearshoring and reshoring strategies are being considered to reduce the dependence on overseas production, develop essential economic activities at a regional/local level, and increase supply chain resilience (Notteboom and Haralambides 2020). In the parallel way there is possibility to substitute JustIn-Time model by Just-In-Case approach in global Supply Chain system.

\section{The Covid-19 Pandemic for Global Economic Outlook}

A serious negative impact was seen across all forms of socio-economic activities due to the pandemic. With the spread of the virus from China to other countries, many countries have reported a decline in economic growth (Bamfo, 2020). With the reference to the warning of the World Health Organization (WHO) in contradiction of various Covid-19 cases that was noticed at the end of December 2019 in China. The information regarding an outbreak risk began to blowout rapidly in the world and speed up deteriorations in national economic growth.

Expectations were met and the global economy shrank by -3.3 percent in pandemic year of 2020. Advanced Economies faced - 4.7 Growth for 2020, However 2021 is targeted by $5.1 \%$, while 2022 defined to grow by $3.6 \%$. Emerging Market and Developing Economies contracted $-2.2 \%$ growth, nevertheless 2021 is prominently forecasted with $6.7 \%$ growth, following 2022 with 5.0\% Annual growth. If we compare the COVID-19 to 2008 global financial crisis we can say that recession in 2020 was smaller scars than the mentioned financial crisis. However, Advanced Economies have been hit harder than Emerging market economies and low-income developing countries and they are expected to suffer more substantial in long term period. 
Figure 1. Overview of the World Economic Outlook \& Projections (Percent change, unless noted otherwise)

\begin{tabular}{lrrr}
\hline & & \multicolumn{3}{c}{ Projections } \\
\cline { 3 - 5 } & 2020 & 2021 & 2022 \\
\hline World Output & -3.3 & 6.0 & 4.4 \\
Advanced Economies & -4.7 & 5.1 & 3.6 \\
United States & -3.5 & 6.4 & 3.5 \\
Euro Area & -6.6 & 4.4 & 3.8 \\
Germany & -4.9 & 3.6 & 3.4 \\
France & -8.2 & 5.8 & 4.2 \\
Italy & -8.9 & 4.2 & 3.6 \\
Spain & -11.0 & 6.4 & 4.7 \\
Japan & -4.8 & 3.3 & 2.5 \\
United Kingdom & -9.9 & 5.3 & 5.1 \\
Canada & -5.4 & 5.0 & 4.7 \\
Other Advanced Economies ${ }^{2}$ & -2.1 & 4.4 & 3.4 \\
Emerging Market and Developing Economies & -2.2 & 6.7 & 5.0 \\
Emerging and Developing Asia & -1.0 & 8.6 & 6.0 \\
China & 2.3 & 8.4 & 5.6 \\
India ${ }^{3}$ & -8.0 & 12.5 & 6.9 \\
ASEAN-5 & -3.4 & 4.9 & 6.1 \\
Emerging and Developing Europe & -2.0 & 4.4 & 3.9 \\
Russia & -3.1 & 3.8 & 3.8 \\
Latin America and the Caribbean & -7.0 & 4.6 & 3.1 \\
Brazil & -4.1 & 3.7 & 2.6 \\
Mexico & -8.2 & 5.0 & 3.0 \\
Middle East and Central Asia & -2.9 & 3.7 & 3.8 \\
Saudi Arabia & -4.1 & 2.9 & 4.0 \\
Sub-Saharan Africa & -1.9 & 3.4 & 4.0 \\
Nigeria & -1.8 & 2.5 & 2.3 \\
South Africa & -7.0 & 3.1 & 2.0 \\
\hline & -1 & & \\
& & &
\end{tabular}

Source: IMF, World Economic Outlook

Figure 2. Global Growth

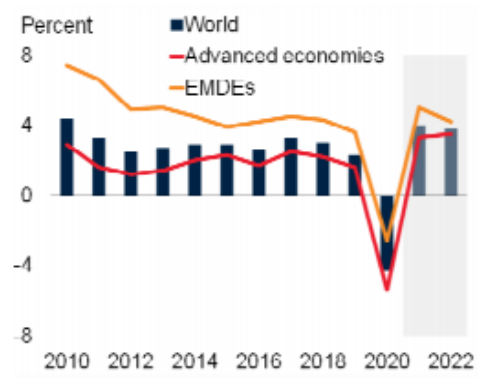

Figure 3. Regional growth

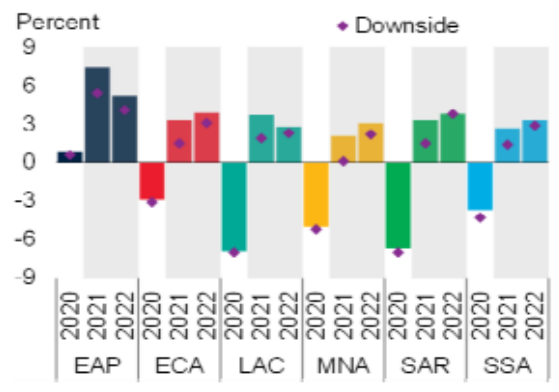

Source: World Bank

Since China National Lockdown was announced western countries declared their restrictions on their boarders. Thus, the world trade volume (Goods \& Services) decreased by $8.5 \%$ within Pandemic in 2020, where imports declined by $8.85 \%$ and exports shrunk by $7.6 \%$ for Advanced, Emerging and Developing Economies totally. Forecast for 2021-2022 distinct with accordance of $8.4 \%$ and $6.5 \%$ annual growth (IMF). If we look at trade structure, we can say that import and export volumes drastically declined mostly for Advanced Economies, rather than Emerging and Developing 
States. Total imports for 2021 is expected to be increased by $9.05 \%$, while export targeted for $7.75 \%$ growth.

In addition to above, consumer prices slightly increased for Advanced Economies (0.7\%), while there was significant growth for Emerging Market and Developing Economies which made up 5.1\% in 2020. 2021 is targeted with important increase of consumer prices levels mostly for Emerging Markets \& Developing Economies with 4.9\%, while the same indicator will not exceed 1.6\% increase for Advanced Economies in 2021.

Figure 4. Overview of the World Economic Outlook \& Projections

(Percent change, unless noted otherwise)

\begin{tabular}{|c|c|c|c|}
\hline & \multirow[b]{2}{*}{2020} & \multicolumn{2}{|c|}{ Projections } \\
\hline & & 2021 & 2022 \\
\hline $\begin{array}{l}\text { World Trade Volume (goods and services) } \\
\text { Imports }\end{array}$ & -8.5 & 8.4 & 6.5 \\
\hline Advanced Economies & -9.1 & 9.1 & 6.4 \\
\hline Emerging Market and Developing Economies & -8.6 & 9.0 & 7.4 \\
\hline \multicolumn{4}{|l|}{ Exports } \\
\hline Advanced Economies & -9.5 & 7.9 & 6.4 \\
\hline Emerging Market and Developing Economies & -5.7 & 7.6 & 6.0 \\
\hline \multicolumn{4}{|l|}{ Commodity Prices (US dollars) } \\
\hline & -32.7 & 41.7 & -6.3 \\
\hline $\begin{array}{l}\text { Nonfuel (average based on world commodity import } \\
\text { weights) }\end{array}$ & 6.7 & 16.1 & -1.9 \\
\hline \multicolumn{4}{|l|}{ Consumer Prices } \\
\hline Advanced Economies ${ }^{6}$ & 0.7 & 1.6 & 1.7 \\
\hline Emerging Market and Developing Economies ${ }^{7}$ & 5.1 & 4.9 & 4.4 \\
\hline
\end{tabular}

Source: IMF, World Economic Outlook

Since outbreaks of the pandemic commodity prices have started immense fluctuation. Drastical drop down have been seen mainly on crude oil. Less decrease was faces in agriculture and metals. Consistent with the projected global recovery, oil prices are projected to grow $30 \%$ in 2021. Metal prices are projected to accelerate strongly in 2021, largely reflecting the rebound in China. Food prices are also expected to pick up this year.

Figure 5. Commodity Price Indexes Figure 6. OPEC+ Crude Oil Production
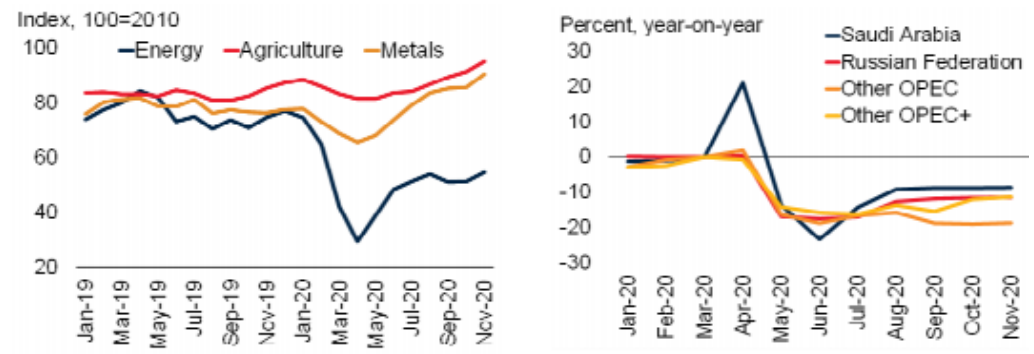


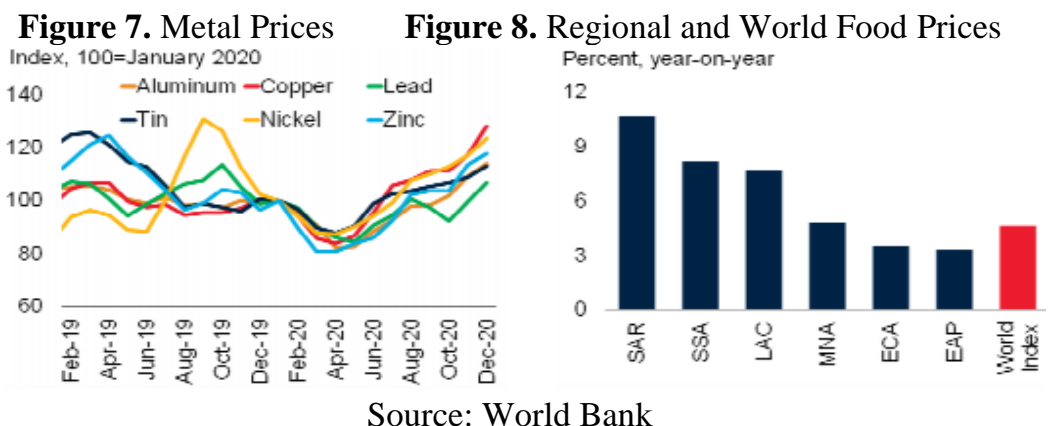

In April 2020, the most affected industry with dramatic cut in production was revealed: motor vehicles, following by textile and aerospace. Nevertheless, the mentioned industries managed to boost Production level within next three months, but sharply increase still does not reach PrePandemic level till the end of 2020. 2021 defined as potential increase for Industries spatially in Asian region - mostly in China, which is not incorporated in the presented Charts. Global current account balances widened in 2020 and are projected to extend further in 2021 as well.

Figure 9. Global Manufacturing: Selected Industries

(Index, December $2019=100$; seasonally adjusted)

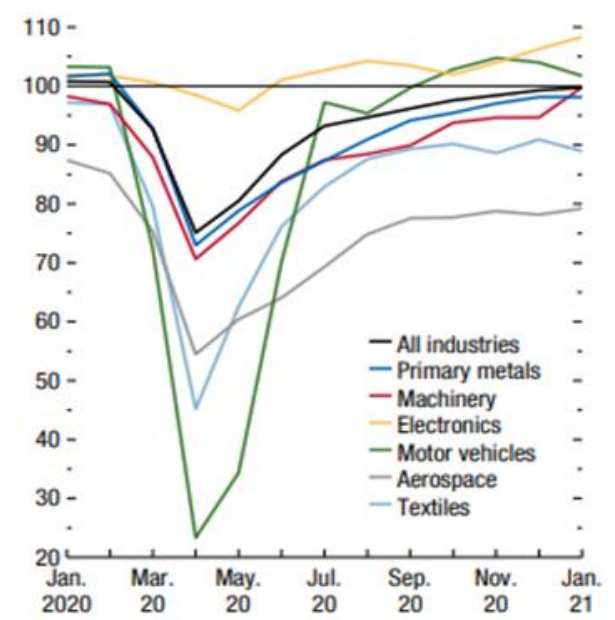

Source: Haver Analytics; and IMF. Note: Excluding China. 
Figure 10. Global Manufacturing, by Industry

(Contribution to year-over-year percent change; percentage points)

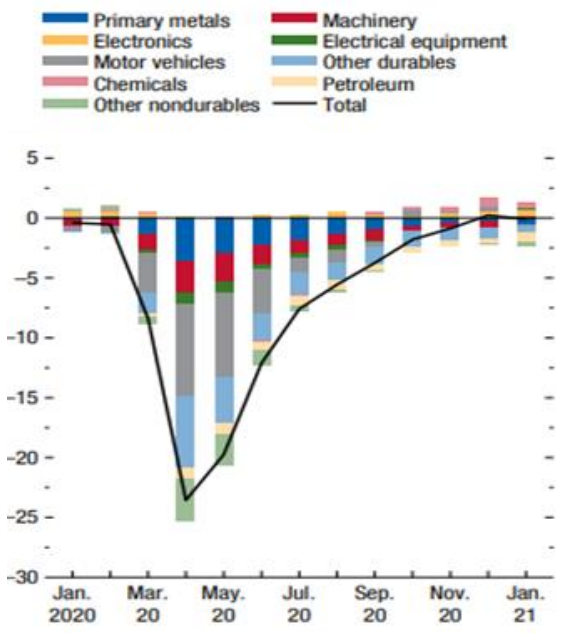

Source: Haver Analytics; and IMF. Note: Excluding China.

\section{Reflection on Global Container Shipping Industry}

Ever since the first case of coronavirus in Wuhan was reported on the 30th of December 2019, the global economy has been one of the worst to be affected. The outbreak of major contagious diseases is noted to destruct the economy through numerous channels (Madhav, 2017).

China as the first to be affected by this pandemic underwent a strict lockdown of some provinces with increasing cases Notwithstanding the strict enforcement of COVID-19 preventive measures by China to contain the spread of the COVID-19, the virus crossed the borders of China to other countries (Ayittey, 2020). Thus, Economic activities started to decline in China by which worldwide supply chain networks have also been disturbed. Economic Industries across the world which were immensely dependent on resource contributions from the Chinese economy have also encountered reductions in manufacturing and production. Besides, international complex Logistical services including almost all transportation modes have been negatively affected and further slowed Supply Chain system operations. Most prominently, anxiety among customers and businesses has also influenced usual consumption arrangements and created marketplace irregularities (Jawad, Maroof, Naz, 2021).

The Covid-19 pandemic has undoubtedly impacted all aspects of global economy and main industries. Consequently, the Pandemics has significantly affected the Maritime industries development (including shipping operators, port operators, government authorities, shippers, seafarers, supply chain operators, etc.). We observed Global Supply Chain issues in the context of Global Container shipping industry. 
Before the fall in container volume in 2019, the containerized cargo flow was performing prominently. Between 2003 - 2018, global container volume increased by an annual average rate of more than $35 \%$. There can be identified several reasons behind of the historically very high growth in containerized shipping Industry such as: Increasing level of liberalization of Global trade (e.g., China's WTO accession in 2001) and share of goods and raw materials that are ideal for shipping via container (semis and finished products); Advances in container technology (e.g., containers for refrigerated goods or liquids, as well as for OOG cargoes); Simplifications on Container ships possess over traditional general cargo freighters: shorter loading and unloading times reduce turnaround times in the port, which cuts costs. Moreover, options for onward conveyance via other modes of transport are better with containers than with general cargo. Ever bigger and faster so-called Mother vessels have allowed continuous productivity improvements resulted increase in capacity has cranked up the price pressure in the sector. Finally, we should emphasize capital investments in seaport infrastructure that has been and remains essential for fast growth around the World.

Nevertheless, 2019 year became a bunch of challenges for Global container industry. The main factors of immense industrial encounters were raised trade regulation (e.g., US-China trade war) and the conditions of shipping fleet deployment, green shipping, and green port issues (e.g., Sulphur content in fuels).

The impact of US-China Trade War drastically damaged the global container shipping business in 2019. Total volume of container trade has shrunk more than by $8 \%$, according to Shipping Intelligence Network. Owing to decreased demand Freight rates dropped down almost by 5\% and 6\% of the fleet was placed up, which means that in 2019 about 300 vessels had been abolished. Eventually the industry faced operational and financial losses. In the same year available container amount increased by more than $4 \%$ at China main ports and by more than $2 \%$ worldwide. The biggest decline of around $6 \%$ was dispatched by the west coast of United States ports.

Over the last decade, global economic and trade processes, as well as ongoing changes in the Global container shipping industry have been developing with China's direct involvement. Almost $70 \%$ of global container throughput is handled by main seaports in Asia. In 2019, nine out of the ten biggest container seaports in the world were in Asia and China was the leader in this respect, owner of 6 out of the current top 10 ports (Shanghai, NingboZhoushan, Shenzhen Guangzhou, Hong Kong, Qingdao, and Tianjin). According to shipping route we can see that at least one port in Asia is involved in around 50\% of all containerized shipments. This shows that global containerized shipping benefits not only from the manufacturing in Asia of 
consumer goods for EU or USA, but also trade relations and the international division of labor between Asian countries have enlarged immensely too.

Covid-19 has immediately disrupted the global economy and automatically negatively reflected on container shipping industry. Shipping is a main industry for almost all countries globally and plays an integral role in the supply chain for most industries. It means that we are much dependent on the shipping industry to transport food, medicine, and other necessities across borders, on the other hand, the industry lay on production to secure cargoes. Thus, we can say that the shipping industry is very much based on circularity and COVID-19 has caused huge disturbances in the global supply chain. To analyze reflection of Covid-19 pandemic on global container shipping industry we define two main directions such as: economic and industry impacts.

In the end of first quarter of 2020, many countries announced lockdown, and economic activities were restricted. Temporarily closed factories generate disruption in production process resulted on internal as well as external trade disbalance. As a result, National Economies faced Economic downfall. China was the first country entered in lockdown as the virus broke out from the state. Finally, second quarter of pandemic year started with drastically imbalanced global trade which can be defined as direct Economic Impact of Covid-19 Pandemic.

Figure 11. Determinants of Economic Impact

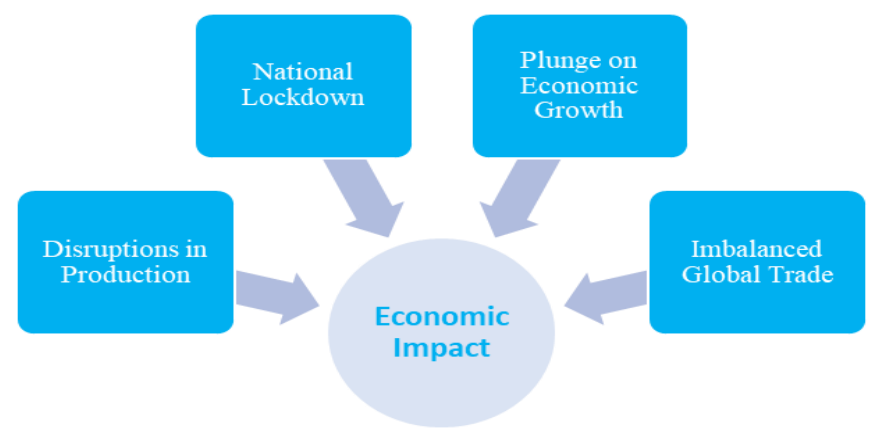

Source: Author's illustration

Above mentioned economic impact immediately turned into industrial impact for global container shipping industry. Therefore, with lockdowns and closed factories, the pandemic has put a strain on the Container shipping industry. Once China's Government decided to close factories and enter in lockdown Global Shipping Lines announced blank sailings to China's main ports and skipped port calls accordingly to maintain freight and avoid economic losses.

Meanwhile, there was tremendously increased number of corona cases among maritime industry employees. Increased cases significantly reduced the 
number of port staff and slowed down speed of cargo handling procedures. Thus, slowdown in maritime supply chain and port congestion cause lack of intermediate goods from China with a result of many companies to suffer. Commodity prices significantly decreased; particularly crude oil saw the lowest rate level over last decade. Eventually, almost all countries resulted with negative economic growth in the second quarter of 2020 pandemic year. Since third quarter of pandemic year, global economic activities started to recover with cautious steps firstly from China. Then, many countries reaccelerated their domestic as well as export-oriented production especially from China to USA and Europe. In the same time, owing to blank sailings by Global Shipping Lines and abolished port calls in China shifted geography of container trade. This means that shipping lines still operated with fewer vessels. Western countries were taking selective measures by allowing economic activities for production for certain time and closing them again the next. This irregular goods flow created operational issues with port congestion and shipping companies decided not to call china main ports due to the long waiting times.

Beside above-mentioned increased corona cases in the countries navigated capacity constraints on inland transport systems including rail modes and trucking systems. Additional corona testing procedures raised operational burden and huge crews on border crossing procedures, mostly in multimodal transit corridors. Delays generated demurrage and detention costs for cargo owners resulted with additional financial losses for shipper/consignees. Another operational setback was occurred due to delays by factories which were not able to return containers back to terminals to proceed with shipment smoothly. These factors meant that container dwell times increased, and empty containers could not return to the system in which they were most needed (UNCTAD, 2020).

Figure 12. Determinants of Industry Impact

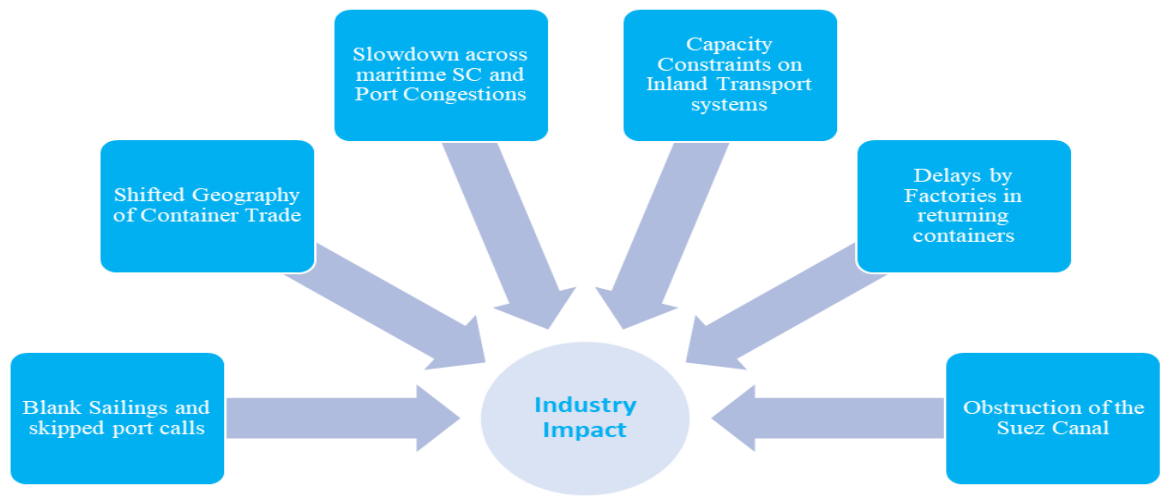

Source: Author's illustration 
Thus, demand heavily exceeded supply and freight rates went through the roof accordingly. In a result Global container shipping industry troubled by a shortage of containers and space (absence of operating vessels) availability which automatically caused a surge in freight rates accordingly.

Once China's economy started recovery at the beginning of third quarter of pandemic 2020 increase in demand of empty containers and space availability was stronger than expected and not match with an adequate supply of marine capacity. Empty containers to move exports from China to Europe and USA became difficult. Therefore, the disruptions in global production initially in China case resulting from the Covid-19, trade imbalances and changing trade patterns commanded to shifts in the geography of container trade. Empty boxes were left in places where they were not requested. Furthermore, as major shipping lines announced the blank sailings with skipped port calls, a mismatch between supply and demand for empty containers was aggravated, as empty containers were left behind and could not be repositioned.

The latest Factor exacerbated Industry impact can be defined the situation by the obstruction of the Suez Canal by a grounded container ship. Vessels in crew, and the containers on them could not manage to bang on time within defined transit time resulted huge delay to reach destinations, eventually the case exacerbated issues regarding shortage of containers and space availability level. Thus, freight rates increased on almost all routes having connection with the canal.

Considering all presented determinants containers stuck in the wrong ports or delayed by several weeks. Containers are piled up in north America \& Europe, where they are not needed, while Asian countries have been in desperate need especially in China.

Figure 13. Results of Economic and Industry impacts

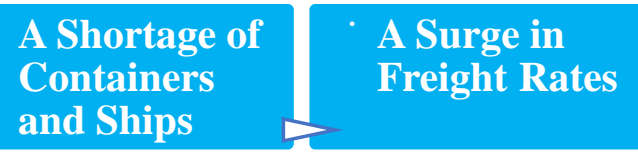

Source: Author's illustration

The interdependent tendencies described above concluded in freight rates reaching historical highs by the fourth quarter of 2020. The surge in freight rates spread across all regions but mostly observed on the main EastWest routes. In comparison, the lowest relative increase in freight rates was recorded on the Asia-East Coast North America route increase by almost 62 $\%$, while ocean rates from China to South America were more than $440 \%$ higher than the median for that route. 
Figure 14. Shanghai containerized freight index, weekly spot rates,

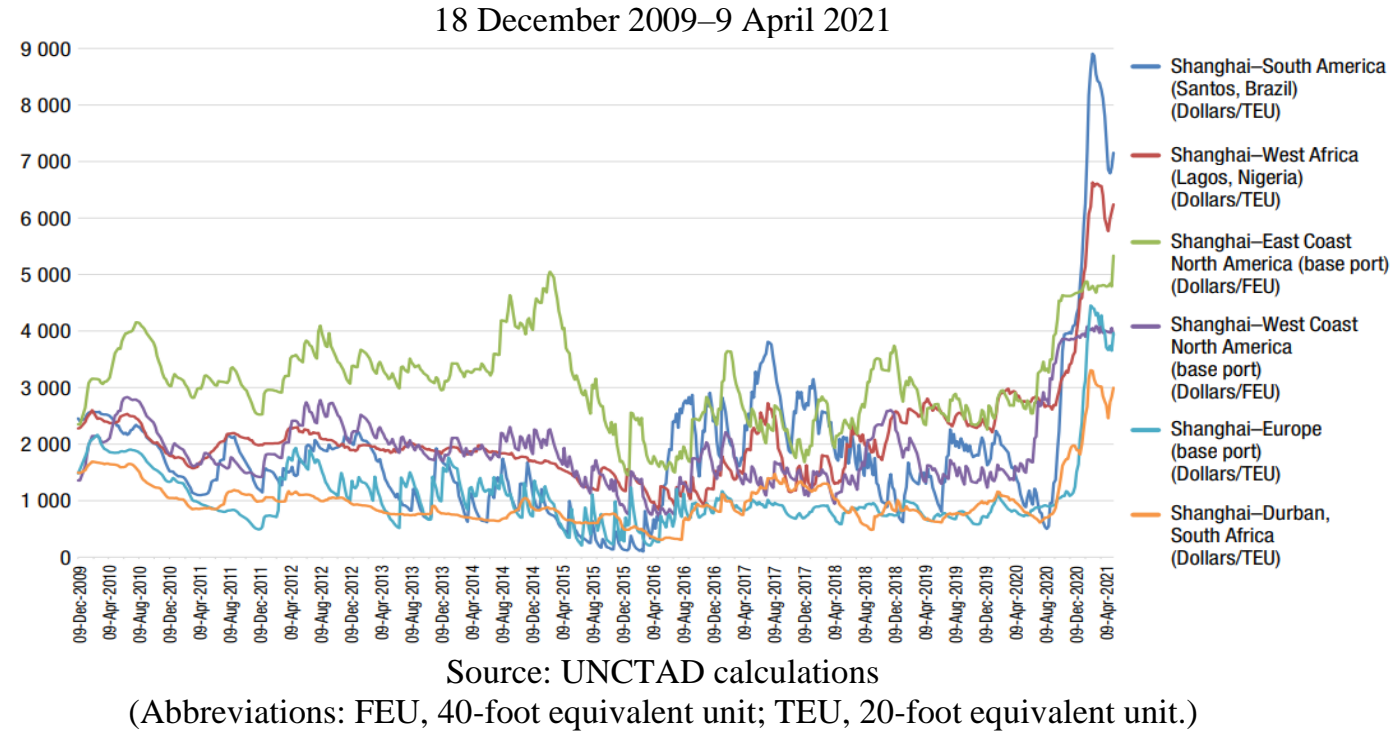

Despite the negative expectations that Covid-19 pandemic would slump global containerized cargo trade, changes in consumption and shopping patterns by intensification electronic commerce surprisingly triggered. As in the third quarter of 2020, declining of lockdown measures and starting of economic activities recovery worldwide, also stimulus packages introduced by various countries supporting consumer demand, inventory-building and frontloading in anticipation of new waves of the virus, supported to a further growth in containerized cargo flows.

\section{Conclusion}

Because economy remains hostage to medicine (Papava, 2020a) it is quite difficult to make a forecast even for the next few months. Nevertheless, Covid-19 pandemic will have short-term and long-term impact on the global container shipping industry with necessity to adapt to possible changes in global supply chain system.

The highly uncertain environment of global market volatility in the first half of Pandemic Year was followed by a recovery started in the third quarter of 2020, with highly uncertain circumstances caused by a new wave of the virus and Lockdowns in countries worldwide. Almost all international organizations such as: World Bank, IMF, OECD etc. revised their outlooks about future growth.

In short term prospective going forward in 2021 the issue regarding shortage of containers and space on vessels will possibly remain unchanged. Therefore, by continuing mismatch between demand and supply freight rates will be kept on high level too. Besides, owing to intensified cargo inspection 
measures on ocean as well as on inland part including delays in border crossing procedures most likely will increase cost on combined logistical services. Nevertheless, because of temporary trade barriers and export restrictions on ocean there is possibility to increase in alternative logistical solutions on intercontinental rail services for East-West trade facilitation.

From the point of long-term prospective global container shipping industry will increase speed of digitalization process by investing in new technologies to support automation trend in the industry to reduce labor deficiency. Besides, we should expect increase in the international division of labor, rising incomes and consumption opportunities in developing economies and emerging markets mostly in China. In order to avoid gap between future possible increase of containerization level worldwide and capacity of global container shipping industry there is expectation to launch bigger vessels as well as more efficient loading and unloading systems at seaport terminals which will create leverage to gain scale of economy for shipping operators as well. Due to Pandemic experience regarding arose setbacks in production by several lockdowns there may shift from Just in-time into Just-in-case model in global manufacturing. As Maritime industry plays a key role in global supply chain system which is directly depends on global manufacturing and retailing process it will be needed to adopt those changes by container shipping industry worldwide. As we saw global value chains have been mainly vulnerable toward national lockdowns. Therefore, there we may expect development of shorter supply chains, an increase in alternative logistic solutions such as intercontinental rail services and introduce multifunctional warehouses close to the markets to cut transit time to destinations.

Above suggested development should be considered with subject to several determinants such as political challenges and risks among main regional countries; International economic challenges (US-China Trade War); Global Health context (level of Vaccination); Tightening Environmental Regulation by International Maritime Organization; Capacity bottlenecks at seaports; fluctuations on fuel prices and post pandemic development of national trade policies worldwide as there is risk of rise of protectionism approaches from governments in order to boost domestic production to increase global competitiveness on certain type of commodities.

\section{References:}

1. Arora, S. et al (2020) Resilience in transport and logistics. McKinsey \& Company.

https://www.mckinsey.com/business-functions/operations/ourinsights/resilience-in-transport-and-logistics 
2. Ayittey, F., Ayittey, M., Chiwero, N., Kamasah, J. and Dzuvor, C. (2020) Economic Impacts of Wuhan 2019-nCoV on China and the World. Journal of Medical Virology.

https://www.researchgate.net/publication/339209152_Economic_Imp acts_of_Wuhan_2019-nCoV_on_China_and_the_World

3. Baker, P. (2020) The Impact of COVID-19: Reflections on the Transport and Logistics Sector.

https://www.tradeeconomics.com/iec_publication/impact-covid19transport-logistics/

4. Ghosh, J. (2020) The Pandemic and the Global Economy https://council.science/current/blog/the-pandemic-and-the-globaleconomy/

5. Jackson, J., Weiss, M., Schwarzenberg, A., \& Nelson, R. (2020, April 17). Global economic effects of COVID-19. Washington, DC: Congressional Research Service.

https://lmic-cimt.ca/now-of-work/jackson-j-weiss-m-schwarzenberga-nelson-r-2020-april-17-global-economic-effects-of-covid-19washington-dc-congressional-research-service-added-2020-27-04/

6. Jawad, M., Maroof, Z. and Naz, M. (2021) Impact of Pandemic COVID-19 on global economies (a seven-scenario analysis). https://www.researchgate.net/publication/350632889_Impact_of_Pan demic_COVID-19_on_global_economies_a_seven-scenario_analysis

7. Knowler, G. (2020a) Extent of Chinese Factory Slump Supports Fears over Inventory Levels. Journal of Commerce.

8. Leonard, M. (2020) Blank Capacity Nears 4 M TEUs with Carriers Planning Q3 Cancellations. www.SupplyChaindive.com

9. Madhav, N., Oppenheim, B., Gallivan, M., Mulembakani, P., Rubin, E. and Wolfe, N. (2017) Pandemics: Risks, Impacts, and Mitigation. https://www.ncbi.nlm.nih.gov/books/NBK525302/

10. Muhammad, F. (2020) COVID-19 Pandemic: A Global Economic Challenge.

https://www.researchgate.net/publication/342355026_COVID-

19_Pandemic_A_Global_Economic_Challenge

11. Notteboom, T., Pallis, T. \& Rodrigue, (2021) Disruptions and resilience in global container shipping and ports : the COVID-19 pandemic versus the 2008-2009 financial crisis https://biblio.ugent.be/publication/8685921

12. Papava, V. \& Chkuaseli, M. (2021) Economic Consequences of the COVID-19 Pandemic and the Economic Ability of a Government as a Factor of Production. 
https://www.academia.edu/47729301/Economic_Consequences_of_t he_COVID_19_Pandemic_and_the_Economic_Ability_of_a_Govern ment_as_a_Factor_of_Production

13. Papava, V. (2020a) Coronomic Crisis: When The Economy Is a Hostage to Medicine. Eurasia Review, March 29. Available at https://www.researchgate.net/publication/340264785_Coronomic_Crisis _When_The_Economy_Is_A_Hostage_To_Medicine.

14. Papava, V. (2020b) Is the Vaccine a Panacea? Eurasia Review, September 30.

https://www.eurasiareview.com/30092020-is-the-vaccine-a-panaceaoped/?fbclid=IwAR0A1A6aQRGpC6SfhcjjtneRU34HGm920joNgHsnZMIO4raEsLWO815Jrs.

15. Singh, S., Kumar, R., Panchal, R. and Tiwaria, T. (2020) Impact of COVID-19 on logistics systems and disruptions. in food supply chain https://www.tandfonline.com/doi/full/10.1080/00207543.2020.17920 00

16. Udoy, K. (2021) Impact of COVID-19 Pandemic on Global Economy and the Direct and Indirect Impact on Bangladesh Economy. Department of Economics University Dhaka.

17. https://www.researchgate.net/publication/350659901_Impact_of_COVID 19_Pandemic_on_Global_Economy_and_the_Direct_and_Indirect_Impa ct_on_Bangladesh_Economy

18. Bamfo, I. (2020) COVID-19 and Global Economy: A Review . Journal of Advocacy, Research and Education

https://www.researchgate.net/publication/350319449_Covid-

19_and_Global_Economy_A_Review

19. UNCTAD, (2020) Review of Maritime Transport 2020. Geneva.

20. World Health Organization, (2020). Shortage of Personal Protective Equipment Endangering Health Workers Worldwide, News Release, Geneva.

21. Yang, D., Jiang, L., Notteboom, T. (2019) Innovative Solutions for Shipping Market Turmoil: The Search for Profitability, Sustainability and Resilience. Transport Policy.

22. https://www.ifc.org

23. https://www.imf.org

24. https://www.oecd.org

25. https://www.worldbank.org 